\title{
Vitamin D and Metabolic Syndrome in Immigrant East Asian Women Living in Sydney, Australia: A Pilot
}

Kaye E Brock ${ }^{1 *}$, Liang Ke ${ }^{1}$, Fung Koo ${ }^{2}$, Haeyoung Jang ${ }^{1}$, Lindy Clemson ${ }^{1}$, Elias Mpofu', Marilyn Tseng ${ }^{3}$, David R Fraser ${ }^{4}$, Markus J Seibel and Rebecca S Mason ${ }^{6}$

${ }^{1}$ Faculty of Health Sciences, University of Sydney, Australia

${ }^{2}$ Sydney Nursing School, University of Sydney, Australia

${ }^{3}$ Department of Kinesiology, California Polytechnic State University, San Luis Obispo, CA, USA

${ }^{4}$ School of Animal Sciences, Faculty of Veterinary Sciences, University of Sydney, Australia

${ }^{5}$ ANZAC Research Institute \& Endocrinology, Concord Hospital, University of Sydney, Australia

${ }^{6}$ Physiology \& Bosch Institute for Medical Research, Sydney Medical School, University of Sydney, Australia

\begin{abstract}
Background: As epidemiological studies have linked vitamin D deficiency to risk of metabolic syndrome, we investigated vitamin $D$ deficiency with metabolic syndrome prevalence in immigrant Asian women.

Materials and Methods: In a cross-sectional pilot survey of older East Asian women ( $\mathrm{n}=85$ aged $60-95)$ we examined the association between vitamin D status (measured by serum 25-hydroxyvitamin D) with metabolic syndrome risk factors.

Results: The population mean for 25-hydroxyvitamin $D$ concentration in serum was $56 \pm 22 \mathrm{nmol} / \mathrm{L}$ with forty percent being vitamin $D$ deficient $(<50 \mathrm{nmol} / \mathrm{L})$. Ninety-eight percent of the population had at least one metabolicsyndrome risk factor, $85 \%$ had two, $55 \%$ had three and $8 \%$ had four. Having four metabolic syndrome risk factors was associated with a three fold risk of vitamin $\mathrm{D}$ deficiency. Vitamin $\mathrm{D}$ deficiency was associated with high non-fasting blood glucose levels $\geq 7.7 \mathrm{mmol} / \mathrm{L}(\mathrm{OR}=5.2,95 \% \mathrm{Cl}=1.8-18)$ and non-significantly, with being overweight $(\mathrm{OR}=1.8$, $95 \% \mathrm{Cl}=0.7-5)$. In contrast, vitamin D deficiency was not associated with either hypertension or central obesity. Environmental factors associated with vitamin $\mathrm{D}$ deficiency in these data were no vitamin tablet intake (calcium or vitamin $\mathrm{D})(\mathrm{OR}=7.2,95 \% \mathrm{Cl}=1.8-29$; $\mathrm{OR}=6.3,95 \% \mathrm{Cl}=1.2-32$, respectively); not being acculturated to an Australian lifestyle, $(\mathrm{OR}=2.6,95 \% \mathrm{Cl}=0.9-8)$ or less sun exposure on the weekends $(\mathrm{OR}=3.6,95 \% \mathrm{Cl}=1.0-13)$. After adjustment for these predictors, if these Asian immigrants were vitamin $\mathrm{D}$ deficient they were at an eight fold risk of having high blood glucose measurements $(\mathrm{OR}=7.6,95 \% \mathrm{Cl}=1-53)$.
\end{abstract}

Conclusion: Further larger prospective studies should be conducted to examine the association between vitamin $\mathrm{D}$ deficiency and risk of metabolic syndrome in similar immigrant populations.

Keywords: Metabolic syndrome; Vitamin D predictors; 25(OH)D; Asian immigrant; Women; Blood glucose levels; Australia

\section{Introduction}

Established determinants of vitamin D status, as measured by serum 25-hydroxyvitamin $\mathrm{D}(25(\mathrm{OH}) \mathrm{D})$ are exposure to sunlight and intake of vitamin $\mathrm{D}$, either from foods or vitamin supplements [1]. Decreased physical activity, obesity and low social status and darker skin tone have also been associated with low vitamin D levels worldwide [2]. Several recent reviews have reported associations between low blood 25(OH)D levels and metabolic syndrome (MetS) risk factors such as hypertension, diabetes and coronary heart disease(CHD) [36]. Thus we investigated the association between vitamin D deficiency and individual MetS risk factors (hypertension (i.e. systolic/diastolic greater than 130/85), high non-fasting blood glucose, being overweight and having central obesity), along with other environmental and demographic risk factors in a pilot study of a healthy group of older East Asian immigrant women living in Sydney, Australia.

\section{Materials and Methods}

Participants $(\mathrm{n}=85)$ were recruited through Asian (Chinese and Korean) community organizations. These women were asked to donate a blood sample and measurements were taken for height, weight, waist and blood pressure. Blood pressure was measured from the right arm with a mercury sphygmomanometer under standardized conditions. The lower of two measurements at least one minute apart was recorded.

They were also helped to complete an interview administered questionnaire including information on demographics, physical activity, foods (a check list of foods high in calcium and vitamin D), vitamin supplement intake and acculturation and sunlight exposure on week days and weekends. The acculturation questions were adapted to the Australian environment from an American acculturation scale which has showed good reliability and validity in other East Asian immigrant studies [7]. The questionnaire was translated (and back translated) to and from either Cantonese or Korean and researchers of both nationalities were involved in the data collection phase of the study.

Serum samples collected were divided; one aliquot was tested for blood glucose in a standard pathology laboratory while the other was stored at $-70^{\circ} \mathrm{C}$ and subsequently analysed for $25(\mathrm{OH}) \mathrm{D}$ by radioimmunoassay (DiaSorin). The mean intra-assay coefficient of variation $(\mathrm{CV})$ in $25(\mathrm{OH}) \mathrm{D}$ analyses was $5 \%$ with a range of $0-25 \%$. Blood samples were drawn in spring $(n=67)$ and the end of summer $(\mathrm{n}=18)$.

*Corresponding author: Dr. Kaye E Brock, Faculty of Health Sciences, University of Sydney, East Street (PO Box 170), Lidcombe NSW 2141, Australia, Tel: +61 2 9351 9124; Fax: +61 29351 9540; E-mail: Kaye.Brock@sydney.edu.au

Received November 03, 2011; Accepted January 27, 2012; Published March 01, 2012

Citation: Brock KE, Ke L, Koo F, Jang H, Clemson L, et al. (2012) Vitamin D and Metabolic Syndrome in Immigrant East Asian Women Living in Sydney, Australia: A Pilot. J Metabolic Synd 1:103. doi:10.4172/2167-0943.1000103

Copyright: @ 2012 Brock KE, et al. This is an open-access article distributed unde the terms of the Creative Commons Attribution License, which permits unrestricted use, distribution, and reproduction in any medium, provided the original author and source are credited. 
Citation: Brock KE, Ke L, Koo F, Jang H, Clemson L, et al. (2012) Vitamin D and Metabolic Syndrome in Immigrant East Asian Women Living in Sydney, Australia: A Pilot. J Metabolic Synd 1:103. doi:10.4172/2167-0943.1000103

Page 2 of 4

For the purpose of this paper vitamin $\mathrm{D}$ deficiency has been defined as $25(\mathrm{OH}) \mathrm{D}<50 \mathrm{nmol} / \mathrm{L}$. This level has recently been suggested as the cut-point for vitamin $\mathrm{D}$ deficiency as a public health recommendation [3]. The MetS risk factor cut-offs used in this pilot study were on an understudied ethnic immigrant group and thus the cut points used were derived from the existing data: the cut points were made on the value of the mean plus one $\mathrm{SD}$ as the cut point for a high value. These values were: Waist circumference $>80$; $\mathrm{BMI}>23$; non-fasting glucose $\geq$ $7.7 \mathrm{mmol} / \mathrm{L}$ and $\mathrm{SBP} \geq 140$ and $\mathrm{DBP} \geq 85$.

An initial descriptive analysis (based on mean differences and percentages) was performed by $\mathrm{T}$ and Chi-square tests. An analytical analysis of odds ratio (OR) with 95\% confidence intervals (95\% CI) was performed initially to assess environmental predictors of vitamin $\mathrm{D}$ deficiency (Table 1). Backwards elimination linear and logistic regression analysis was performed in order to assess predictors when mutually adjusted for each other.

Subsequently, in Table 2, the associations between individual Met $\mathrm{S}$ risk factors (hypertension, high non-fasting blood glucose, high body mass index (BMI) and high waist circumference) as independent variables and vitamin $\mathrm{D}$ deficiency, as the dependent variable, was assessed both without and with confounding adjustment for the predictors of vitamin D deficiency and the other MetS, as appropriate (again by backwards linear and logistic regression). In both tables OR
(95\% CI) were calculated by logistic regression in order to establish these associations [8]. The study was approved by the Ethics Committee of the University of Sydney (02-2008/10177), with written informed consent obtained from each participant.

\section{Results and Discussion}

In the total population of older East Asian women the mean $25(\mathrm{OH}) \mathrm{D}$ was $56 \pm 22 \mathrm{nmol} / \mathrm{L} ; 40 \%$ of these women were vitamin $\mathrm{D}$ deficient. Ninety-eight percent of the population had at least one metabolic-syndrome risk factor, $85 \%$ had two, 55\% had three and $8 \%$ had four. Having four MetS risk factors was associated with a three fold risk of vitamin D deficiency ( $\mathrm{OR}=3.1,95 \% \mathrm{CI}$ : 0.5-18.3). The sample size of this group limits any further conclusions as these risks are nonsignificant. Factors associated with vitamin D deficiency were: spring season, not taking vitamin $\mathrm{D}$, calcium or multivitamin supplements, having low amounts of sun exposure on weekends and having no acculturation to an Australian lifestyle (Table 1).

When these factors were entered together in a multivariate logistic backwards regression model those: who had no intake of calcium or vitamin D supplements, less sun exposure on the weekends, and were not acculturated to an Australian lifestyle were at seven, six, four and three fold risk of having serum $25(\mathrm{OH}) \mathrm{D}$ level $<50 \mathrm{nmol} / \mathrm{L}$ compared to

\begin{tabular}{|c|c|c|c|c|c|c|c|c|}
\hline & \multicolumn{4}{|c|}{$25(\mathrm{OHD}) \mathrm{nmol} / \mathrm{L} \mathrm{n=85}$} & \multicolumn{4}{|c|}{ Risk of vitamin D deficiency } \\
\hline & $<50 \mathrm{nmol} / \mathrm{L} \mathrm{n}(\%)$ & $\begin{array}{l}\geq 50 \mathrm{nmol} / \mathrm{L} \mathrm{n} \\
(\%)\end{array}$ & Mean (SD) & $p$ value & $\mathrm{OR}^{1}(95 \% \mathrm{Cl})$ & $p$ value & $\mathrm{OR}^{2}(95 \% \mathrm{Cl})$ & $p$ value \\
\hline \multicolumn{9}{|l|}{ Demographic } \\
\hline \multicolumn{9}{|l|}{ Season } \\
\hline After summer & $4(22)$ & $14(78)$ & $67(16)^{*}$ & & 1.0 & & & \\
\hline Before summer & $29(43)$ & $38(57)$ & $54(24)$ & 0.01 & $2.7(0.8-9)$ & 0.11 & & \\
\hline \multicolumn{9}{|c|}{ Level of education } \\
\hline$<$ Secondary & $20(36)$ & $36(64)$ & $55(23)$ & & 1.0 & & & \\
\hline$\geq$ Secondary & $13(45)$ & $16(55)$ & $60(22)$ & 0.35 & $1.5(0.6-4)$ & 0.41 & & \\
\hline \multicolumn{9}{|l|}{ Acculturation } \\
\hline Some & $11(27)$ & $30(73)$ & $61(23)$ & & 1.0 & & 1.0 & \\
\hline None & $22(50)^{*}$ & $22(50)$ & $52(24)$ & 0.10 & $2.7(1.1-7)^{*}$ & 0.03 & $2.6(0.9-8)$ & 0.09 \\
\hline \multicolumn{9}{|c|}{$\begin{array}{l}\text { Sun exposure in weekends } \\
\text { (minutes) }\end{array}$} \\
\hline$\geq 120$ & $19(34)$ & $37(66)$ & $59(23)$ & & 1.0 & & 1.0 & \\
\hline \multirow[t]{2}{*}{$<120$} & $13(46)$ & $15(54)$ & $52(20)$ & 0.14 & $1.7(0.7-4.3)$ & 0.27 & $3.6(1.0-13)^{*}$ & 0.05 \\
\hline & Missing=1 & & & & & & & \\
\hline \multicolumn{9}{|c|}{ Foods + Supplements } \\
\hline \multicolumn{9}{|c|}{$\begin{array}{l}\text { Vitamin D \& Calcium containing } \\
\text { foods (serves/week) }\end{array}$} \\
\hline$\geq 5$ & 11(39) & $17(61)$ & $57(23)$ & & 1.0 & & & \\
\hline$<5$ & 22(39) & $35(61)$ & $56(23)$ & 0.94 & $1.0(0.4-2.4)$ & 0.95 & & \\
\hline \multicolumn{9}{|c|}{ Vitamin D supplementation } \\
\hline Some & $4(18)$ & $18(82)$ & $63(20)$ & & 1.0 & & 1.0 & \\
\hline None & $29(46)^{*}$ & $34(54)$ & $54(23)$ & 0.08 & $3.8(1.2-13)^{*}$ & 0.03 & $6.3(1.2-32)^{*}$ & 0.03 \\
\hline \multicolumn{9}{|c|}{ Calcium supplementation } \\
\hline Some & $4(13)$ & $26(87)$ & $66(17)$ & & 1.0 & & 1.0 & \\
\hline None & $29(53)^{*}$ & $27(47)$ & $51(24)$ & 0.004 & $7.3(2.2-24)^{*}$ & 0.001 & $7.2(1.8-29)^{*}$ & 0.01 \\
\hline \multicolumn{9}{|c|}{ Multivitamin supplementation } \\
\hline Some & $9(26)$ & $25(74)$ & $63(21)$ & & 1.0 & & & \\
\hline None & $24(47)^{*}$ & $27(53)$ & $52(23)$ & 0.02 & $2.5(0.9-6.3)$ & 0.06 & & \\
\hline
\end{tabular}

${ }^{1}$ Crude Odds ratio (OR) and 95\% confidence intervals: i.e., with no adjustment for confounding

${ }^{2}$ Mutually adjusted ORs (backwards regression model)

* $\mathrm{p} \leq 0.05$

Abbreviation: 25(OH)D: 25-hydroxyvitamin D

Table 1: Factors associated with vitamin D deficiency ( $<50 \mathrm{nmol} / \mathrm{L} 25(\mathrm{OH}) \mathrm{D})$ in East Asian immigrant women ( $\geq 60$ years) living in Sydney, Australia 
Citation: Brock KE, Ke L, Koo F, Jang H, Clemson L, et al. (2012) Vitamin D and Metabolic Syndrome in Immigrant East Asian Women Living in Sydney, Australia: A Pilot. J Metabolic Synd 1:103. doi:10.4172/2167-0943.1000103

Page 3 of 4

\begin{tabular}{|c|c|c|c|c|c|c|}
\hline \multirow[b]{3}{*}{$25(\mathrm{OH}) \mathrm{D} \mathrm{nmol} / \mathrm{L}$} & \multicolumn{6}{|c|}{$\begin{array}{l}\text { High glucose } \\
\geq 7.7 \mathrm{nmol} / \mathrm{L}\end{array}$} \\
\hline & \multirow{2}{*}{$\begin{array}{l}<7.7 \\
\text { n (\%) }\end{array}$} & \multirow{2}{*}{$\begin{array}{l}\geq 7.7 \\
n(\%)\end{array}$} & \multicolumn{2}{|l|}{ Linear regression } & \multicolumn{2}{|c|}{ Logistic regression } \\
\hline & & & $\begin{array}{l}\beta^{1} \\
(p \text { value })\end{array}$ & $\begin{array}{l}\beta^{2} \\
(p \text { value })\end{array}$ & $\mathrm{OR}^{1}(95 \% \mathrm{Cl})$ & $\mathrm{OR}^{2}(95 \% \mathrm{Cl})$ \\
\hline$\geq 50$ & $48(92)$ & $4(8)$ & $-0.230^{*}$ & $-0.335^{\star}$ & 1.0 & 1.0 \\
\hline \multirow[t]{3}{*}{$<50$} & $23(70)$ & $10(30)^{*}$ & $(0.03)$ & $(0.01)$ & $5.2(1.8-18)$ & $7.6(1-53)$ \\
\hline & \multicolumn{6}{|c|}{ Overweight $\mathrm{BMI}>23 \mathrm{~kg} / \mathrm{m}^{2}$} \\
\hline & $<23$ & $\geq 23$ & Linear regression & & \multicolumn{2}{|c|}{ Logistic regression } \\
\hline $25(\mathrm{OH}) \mathrm{D} \mathrm{nmol} / \mathrm{L}$ & & & $\begin{array}{l}\beta^{1} \\
\text { ( } p \text { value) }\end{array}$ & $\begin{array}{l}\beta^{2} \\
(p \text { value })\end{array}$ & $\mathrm{OR}^{1}(95 \% \mathrm{Cl})$ & $\mathrm{OR}^{2}(95 \% \mathrm{Cl})$ \\
\hline$\geq 50$ & $17(34)$ & $33(66)$ & -0.035 & 0.001 & 1.0 & 1.0 \\
\hline \multirow[t]{3}{*}{$<50$} & $7(22)$ & $25(78)$ & $(0.11)$ & $(0.92)$ & $1.8(0.7-5)$ & $1.5(0.2-9.5)$ \\
\hline & \multicolumn{6}{|c|}{$\begin{array}{l}\text { High waist } \\
>80 \mathrm{~cm}\end{array}$} \\
\hline & $<80$ & $\geq 80$ & Linear regression & & \multicolumn{2}{|c|}{ Logistic regression } \\
\hline 25(OH)D nmol/L & & & $\begin{array}{l}\beta^{1} \\
(p \text { value })\end{array}$ & $\begin{array}{l}\beta^{2} \\
(p \text { value })\end{array}$ & $\mathrm{OR}^{1}(95 \% \mathrm{Cl})$ & $\mathrm{OR}^{2}(95 \% \mathrm{Cl})$ \\
\hline$\geq 50$ & $5(11)$ & $42(89)$ & -0.208 & -0.075 & 1.0 & 1.0 \\
\hline \multirow[t]{3}{*}{$\geq 50$} & $3(9)$ & 29(91) & $(0.07)$ & $(0.41)$ & $1.2(0.3-5)$ & $1.4(0.1-13)$ \\
\hline & \multicolumn{6}{|c|}{$\begin{array}{l}\text { Hypertension } \\
\mathrm{SBP} \geq 140 / \mathrm{DBP} \geq 85 \mathrm{mmHg}\end{array}$} \\
\hline & Yes & No & Linear regression & Logistic regression & \multicolumn{2}{|c|}{ Logistic regression } \\
\hline 25(OH)D nmol/L & & & $\begin{array}{l}\beta^{1} \\
\text { ( } p \text { value) }\end{array}$ & $\begin{array}{l}\beta^{2} \\
\text { ( } p \text { value) }\end{array}$ & $\mathrm{OR}^{1}(95 \% \mathrm{Cl})$ & $\mathrm{OR}^{2}(95 \% \mathrm{Cl})$ \\
\hline$\geq 50$ & $12(25)$ & $35(75)$ & 0.130 & 0.243 & 1.0 & 1.0 \\
\hline$\geq 50$ & $14(44)$ & $18(56)$ & $(0.25)$ & $(0.08)$ & $0.4(0.2-1)$ & $0.2(0.1-1)$ \\
\hline
\end{tabular}

${ }^{1}$ Crude linear regression Beta $(\beta)$ and logistic regression Odds ratio $(\mathrm{OR})$ and $95 \% \mathrm{Cl} 95 \%$ confidence interval with no adjustment for confounding

${ }^{2}$ Adjusted for confounding by acculturation, vitamin D supplements, calcium supplements, amount of sun exposure on the weekend and other MetS factors where ap-

propriate

* $\mathrm{p} \leq 0.05$

Abbreviations: 25(OH)D: 25-hydroxyvitamin D; BMI: body mass index; SBP: systolic blood pressure; DBP: diastolic blood pressure

Table 2: Association between vitamin $D$ deficiency and cardio-vascular risk in an older population of East Asian Australian female immigrants.

$\geq 50 \mathrm{nmol} / \mathrm{L}$ (OR=7.2, 95\% CI: 1.8-29; OR=6.3, 95\% CI: 1.2-32; OR=3.6, 95\% CI: 1.0-13; OR=2.6, 95\% CI: 0.9-8); respectively (Table 1).

When the association between vitamin $\mathrm{D}$ deficiency and the individual MetS risk factors was investigated and adjusted for confounding factors (Table 2): having a high non-fasting blood glucose was the only factor that was significantly associated with deficient 25(OH)D blood levels ( $\mathrm{OR}=7.6,95 \% \mathrm{CI}=1.0-53)$. Vitamin $\mathrm{D}$ deficiency was not significantly associated with hypertension risk or risk of obesity (either by waist or BMI measurement) in these data.

When these MetS variables were entered as continuous variables against continuous $25(\mathrm{OH}) \mathrm{D}$ blood levels, similar results to the previous

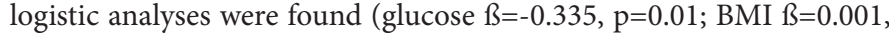
$p=0.92$; waist $\beta=-0.075, p=0.41$; hypertension $\beta=0.243, p=0.08$ ) (Table 2).

The finding of the association between low vitamin $\mathrm{D}$ status and a high non-fasting blood glucose in this study is relevant to Asian populations who are known to be at greater risk of diabetes with increased BMI than any other ethnic group. In a US study it was found that for each five kilograms weight gain, the risk of diabetes in Asians was 2.36 (1.8-3.04) compared to 1.96 (1.93-2.0) in Caucasian populations [9]. In addition high insulin levels have been found to be associated with increased visceral adiposity in non diabetic Asian populations in the US and to dyslipidemia and diabetes risk in Canadian Asians [10]. Genetic loci have been isolated that indicate that South East Asian populations are at more risk of diabetes than other races [11].

Animal studies have suggested that vitamin D can have a direct (via activation of the vitamin $\mathrm{D}$ receptor on pancreatic $\beta$ cells and insulin sensitive organs) and/or indirect (via regulation of calcium homeostasis) affect on increasing insulin secretion and sensitivities $[12,13]$. The epidemiological evidence from cross sectional, casecontrol and cohort studies has shown that lower serum D 25(OH)D levels are associated with obesity, the metabolic syndrome, impaired glucose tolerance and diabetes [14]. Recently, other cohort studies have shown that baseline vitamin $\mathrm{D}$ deficiency is associated with incident cardiovascular disease events and mortality over follow-up, a relationship that may be mediated, in part, through incident diabetes $[4,5,15]$. Thus it is important that these suggestive pilot results (i.e. vitamin $\mathrm{D}$ deficiency being associated with high blood glucose) be followed up in larger observational or intervention studies with a complete array of well measured MetS risk factors.

The findings of a relationship between vitamin $\mathrm{D}$ and calcium supplements use and $25(\mathrm{OH}) \mathrm{D}$ levels in this study is similar to all other studies where vitamin D supplement intake has been recorded [1-6]. The finding that minutes of sun exposure on weekends (not on weekdays or in winter) were predictive of higher vitamin D status in these data are interesting as this may be a good measure of sun exposure in these women. Acculturation is a phenomenon that can occur when individuals of distinct and different cultures come into continuous first hand contact with a host culture, and subsequently experience a change in their original cultural pattern [7]. The acculturation questions which were associated with higher vitamin D status when answered in the affirmative were

- Do you celebrate Australian holidays? 
Citation: Brock KE, Ke L, Koo F, Jang H, Clemson L, et al. (2012) Vitamin D and Metabolic Syndrome in Immigrant East Asian Women Living in Sydney, Australia: A Pilot. J Metabolic Synd 1:103. doi:10.4172/2167-0943.1000103

- Do you eat Australian food at restaurants?

- Do you have Australian friends?

- Do you regard yourself as Australian?

Australian culture is characterized by spending time outdoors and having 'fun in the sun'. A 'healthy' tanned appearance is typically coveted and valued by a Western culture, such as that of Australia [16]. It has generally been accepted that Asian cultures prize lighter skin tones in women [17]. A study in Hong Kong concluded that attitudes and behavior towards sunlight were largely negative and that many of the study participants took measures to avoid sunlight [18]. Two US studies have reported that the rate of deliberate sunbathing among more westernised Asian Americans after acculturation seemed to approach that of White Americans [19-20].

It should be noted that our study is limited by its small sample size, only looking at females and by not having a direct measure of sun exposure or indoor or outdoor exercise patterns, although our measures are adjusted for season of blood draw and have a reported recall of sun exposure on weekends during spring and summer. We also did not have fasting blood glucose measurements. However, the strength of the present investigation is that the measure of vitamin D status and blood glucose were determined from blood analysis of $25(\mathrm{OH}) \mathrm{D}-\mathrm{a}$ rare procedure with immigrant Asian groups as little research has been initiated in these populations and these women are often reluctant to give blood. This is why we could not obtain fasting blood glucose as the community meetings where the study was carried out were held at their normal times, often not in the morning. Despite the lack of fasting blood glucose we believe this pilot study to be important because of the known avoidance of the sun in these populations and also their propensity towards diabetes at a relatively low BMI [21].

Thus, public health intervention efforts should be focused on reducing the risk of diabetes in East Asian immigrant groups. As they may also be at risk of vitamin D deficiency [22], encouraging increased safe sun exposure in summer and increased vitamin D intake either by food or supplements is likely to improve vitamin D status, especially in those less acculturated to Australian customs. In this pilot study of older East Asian Australian immigrant women, we found a 50\% prevalence of vitamin D deficiency. The only MetS risk factor which was associated with this deficiency was having high non-fasting blood glucose.

\section{Acknowledgement}

We acknowledge the input of Augustus Yip and Rosemary Cant who were both involved in the qualitative and acculturation aspects of this project.

\section{References}

1. Ashwell M, Stone EM, Stolte H, Cashman KD, Macdonald H, et al. (2010) UK Food Standards Agency Workshop Report: an investigation of the relative contributions of diet and sunlight to vitamin D status. Br J Nutr 104: 603-611.

2. Lips $P(2010)$ Worldwide status of vitamin D nutrition. J Steroid Biochem Mol Bio 121: $297-300$.

3. Institute of Medicine (10M) 2011 Detairy Reference Intakes for calciumand vitamin D. Washington DC: National Academic Press

4. Burgaz A, Orsini N, Larsson SC ,Wolk A (2011) Blood 25-hydroxyvitamin D concentration and hypertension: a meta-analysis. J Hypertens 29: 636-645.

5. Gagnon C, Lu ZX, Magliano DJ, Dunstan DW, Shaw JE, et al. (2011) Serum 25-hydroxyvitamin D, calcium intake, and risk of type 2 diabetes after 5 years. Diabetes Care 34: 1133-1138.

6. O'Keefe JH, Levie CJ, Holick MF (2011) Vitamin D supplementation for Cardiovascular Disease Prevention. JAMA 306: 1546-1547.

7. Tseng M ,Fang CY (2011) Stress is associated with unfavorable patterns of dietary intake among female chinese immigrants. Ann Behav Med 41: 324-332.
8. Breslow NE, Day NE (1980) Statistical methods in cancer research. Volume I - the analysis of case-control studies. IARC Sci Publ 32.

9. Shai I, Jiang R, Manson JE, Stampfer MJ, Willett WC, et al. (2006) Ethnicity, obesity, and risk of type 2 diabetes in women: a 20 -year follow-up study. Diabetes Care 29: 1585-1590.

10. Gerstein HC, Anand S, Yi QL, Vuksan V, Lonn E, et al. (2003) The relationship between dysglycemia and atherosclerosis in South Asian, Chinese, and European individuals in Canada: a randomly sampled cross-sectional study. Diabetes Care 26: 144-149.

11. Chiu YF, Chuang LM, Hsiao CF, Hung YJ, Lin MW, et al. (2005) An autosoma genome-wide scan for loci linked to pre-diabetic phenotypes in nondiabetic Chinese subjects from the Stanford Asia-Pacific Program of Hypertension and Insulin Resistance Family Study. Diabetes 54: 1200-1206.

12. Norman AW, Frankel JB, Heldt AM, Grodsky GM (1980) Vitamin D deficiency inhibits pancreatic secretion of insulin. Science 209: 823-825.

13. Osei $\mathrm{K}(2010) 25-\mathrm{OH}$ vitamin D: is it the universal panacea for metabolic syndrome and type 2 diabetes? J Clin Endocrinol Metab 95: 4220-4222.

14. Alvarez JA, Ashraf A (2010) Role of vitamin D in insulin secretion and insulin senstivity for glucose homeostasis. Int J Endocrinol 2010: 351-385

15. Knekt P, Laaksonen M, Mattila C, Harkanen T, Marniemi J, et al. (2008) Serum vitamin $\mathrm{D}$ and subsequent occurrence of type 2 diabetes. Epidemiology 19: 666671

16. Albert MR, Ostheimer KG (2003) The evolution of current medical and popular attitudes toward ultraviolet light exposure: part 3. J Am Acad Dermatol 49: 10961106.

17. Hunter M (2007) The persistent problem of colorism: skin tone, status and inequality. Sociology Compass 1: 237-254.

18. Kung A, Lee KK (2006) Knowledge of vitamin D and perceptions and attitudes toward sunlight among Chinese middle-aged and elderly women: a population survey in Hong Kong. BMC Public Health 6: 226.

19. Gorell E, Lee C, Munoz C ,Chanq AL (2009) Adoption of Western Culture by Californian Asian Americans. Arch Dermatol 145: 552-556.

20. Koh HK, Nak SM, Geller AC, Mangione TW, Hingson RW, et al. (1997) Sunbathing Habits and Sunscreen Use among White Adults:Results of a National Survey. Am J Public Health 87: 1214-1217.

21. Lavie CJ, Milani RV, Ventura MO (2011) Imoact of Obesity on outcomes of Myocardial Infarction combating the "Obesity Paradox" J Am Coll Cardiol 58: 2651 2652.

22. Dawson-Hughes B (2004) Racial/ethnic considerations in making recommendations for vitamin $\mathrm{D}$ for adult and elderly men and women. Am J Clin Nutr 80: 1763S-1766S. 